\title{
Stimulation of Suppressive T Cell Responses by Human but not Bacterial 60-kD Heat-shock Protein in Synovial Fluid of Patients with Rheumatoid Arthritis
}

\author{
Joel A.G. van Roon, ${ }^{\star}$ Willem van Eden, ${ }^{\ddagger}$ Johanna L.A.M. van Roy, ${ }^{\star}$ Floris J.P.G. Lafeber, ${ }^{\star}$ and Johannes W.J. Bijlsma* \\ *Department of Rheumatology \& Clinical Immunology, University Hospital Utrecht, 3508 GA Utrecht; and ${ }^{\ddagger}$ Faculty of Veterinary \\ Medicine, Institute of Infectious Diseases \& Immunology, Utrecht University, 3508 GA Utrecht, The Netherlands
}

\begin{abstract}
In several animal models of rheumatoid arthritis (RA), T cell responses to self $60-\mathrm{kD}$ heat-shock protein 60 (hsp60) protect against the induction of arthritis. The nature of this suppressive $T$ cell activity induced by self hsp60 is not clear. In the present study, T cell responses to human (self) hsp60 in RA in terms of type 1 (T1) and type 2 (T2) T cell activity were assessed. The results show that human and not bacterial hsp60-reactive synovial fluid (SF) $\mathrm{T}$ cells of patients with RA proliferate in the presence of the $\mathrm{T} 2$ cell growth factor IL-4. SF T cells stimulated with human hsp60 produced significantly lower amounts of IFN- $\gamma$ and higher amounts of IL-4 than SF T cells stimulated with bacterial hsp60 ( $P \leq 0.002$ and 0.05 , respectively), and consequently a lower T1/T2 cell cytokine ratio was observed for human versus bacterial hsp60 $(P \leq 0.004)$. Additionally, human and not mycobacterial hsp60-specific $\mathrm{T}$ cell lines suppressed TNF- $\alpha$ production. Together, our results suggest that human hsp60, as overexpressed in inflamed synovium of patients with RA, can contribute to suppression of arthritis by the stimulation of regulatory suppressive T cell activity. $(J$. Clin. Invest. 1997. 100:459-463.) Key words: 60-kilodalton heat-shock protein $\bullet$ interferon- $\gamma \cdot$ interleukin- 4 - tumor necrosis factor- $\alpha$
\end{abstract}

\section{Introduction}

In patients with rheumatoid arthritis (RA), ${ }^{1}$ there is a predominance of activated mononuclear cells producing IL- $1, \mathrm{TNF}-\alpha$, and IL-6, cytokines, which are major contributors to inflammatory responses and joint destruction (1-4). Type 1 (T1) cell activity, which has been shown to predominate in the joints of patients with RA (5-8), is known to stimulate macrophages towards production of IL-1 and TNF- $\alpha$ (8). Regulatory type 2

Address correspondence to Joel A.G. van Roon, Department of Rheumatology \& Clinical Immunology (F02.223), University Hospital Utrecht, P.O. Box 85500, 3508 GA Utrecht, The Netherlands. Phone: 31-30-2507357 (7569); FAX: 31-30-2523741.

Received for publication 2 January 1997 and accepted in revised form 17 April 1997.

1. Abbreviations used in this paper: hsp, heat-shock protein; MC, mononuclear cells; RA, rheumatoid arthritis; SF, synovial fluid; TCL, $\mathrm{T}$ cell line.

J. Clin. Invest.

(C) The American Society for Clinical Investigation, Inc.

0021-9738/97/07/0459/05 \$2.00

Volume 100, Number 2, July 1997, 459-463
(T2) cell cytokines, in particular IL-4 and IL-10, have been shown to suppress $\mathrm{T} 1$ responses, IL-1, and TNF- $\alpha$ production and cartilage degradation by RA inflammatory cells from synovial fluid and tissue (9-11). The low level of T2 cell cytokine production in RA has suggested a lack of suppressive T cells in these patients $(5-8,12)$. Remission of $\mathrm{T} 1$ cell-induced arthritis in animals (13) is effectuated by IL-4-producing cells $(13,14)$. Human remitting forms of arthritis have also been suggested to be suppressed by T2 cell activity (7). Therefore, patients with RA may benefit from the activation of regulatory $\mathrm{T}$ cells that provide active cellular suppression through production of suppressive cytokines, such as IL-4 and IL-10. With respect to the induction of suppressive T cells, heat-shock proteins (hsps) may provide antigenic stimuli leading to the immunomodulation of (rheumatoid) arthritis.

Immunization of rats with whole heat-killed Mycobacterium tuberculosis, a T1 cell-promoting condition in humans and rodents $(13,15)$, can lead to (adjuvant) arthritis in rats, which can be transferred by a $\mathrm{T}$ cell clone recognizing a $60-\mathrm{kD}$ mycobacterial hsp (16). However, preimmunization with the isolated mycobacterial hsp60 can protect against the induction of adjuvant arthritis as well as other forms of experimental arthritis (17-21). Protection can also be transferred into naive animals by administration of suppressive hsp60-specific T cell lines, recognizing a specific epitope of self hsp60, strongly homologous to mycobacterial hsp60 (21). Furthermore, administration of (human) hsp60, which has strong homology (95\%) to rat hsp60, before or during induction of arthritis prevented the induction or enhanced remission of adjuvant arthritis (22). In line with this are the observations on patients with juvenile chronic arthritis in which $\mathrm{T}$ cell reactivity to human (self) hsp60 preceded remission of the disease $(23,24)$. The downregulation of experimental and human juvenile chronic arthritis is likely due to recognition of self hsp60 as (over) expressed in the arthritic (stressed) joints of these subjects (25-28). Expression of self hsp60 molecules may activate regulatory T cells, which can cause suppression of $\mathrm{T}$ cells that induce arthritis.

Expression of self hsp60 has also been demonstrated in the synovial tissue of patients with RA (27-29), and reactivity towards both human (30) and mycobacterial hsp60 has been shown in these patients $(31,32)$. Despite the demonstration of cellular and humoral reactivity against hsp60 molecules in RA, a role for these reactivities in terms of induction or suppression of arthritis remains to be elucidated.

We investigated whether lymphocytes from the synovial fluid of patients with RA, treated with human or mycobacterial hsp60, functionally differed in stimulation of IL-4-sensitive T cells. Furthermore, we analyzed the production of T1 (IFN- $\gamma$ ) and T2 (IL-4) cell cytokines by mycobacterial and human hsp60-activated T cells from the synovial fluid of these patients. In addition, we assessed the capacity of mycobacterial and human hsp60-specific T cell lines to suppress proinflammatory cytokine $(\mathrm{TNF}-\alpha)$ production of autologous peripheral blood mononuclear cells. 


\section{Methods}

Patients. Mononuclear cells (MC) were isolated from synovial fluid (SF) of a total of 29 randomly selected patients with RA. RA was defined by the 1987 revised ACR criteria (33). Patients (19 females and 10 males) ranged in age from 19 to $75 \mathrm{yr}$ with a mean age of $52.3 \pm 2.8$ yr. Mean disease duration was $10.4 \pm 1.7 \mathrm{yr}$ with a range of $1-32 \mathrm{yr} .15$ patients were rheumatoid factor positive and 14 were negative. 22 patients received nonsteroidal antiinflammatory drugs, 16 took slowacting antirheumatic drugs, 5 were on low-dose prednisone, and 3 did not receive medication.

Cell cultures and reagents. SF was diluted 1:1 with DMEM and 24 mM NaHCO 3 (074-01600; Gibco Laboratories, Grand Island, NY) containing glutamine $(2 \mathrm{mM})$, penicillin $(100 \mathrm{U} / \mathrm{ml})$, and streptomycin sulfate $\left(100 \mu \mathrm{g} / \mathrm{ml} ; \mathrm{DMEM}^{+}\right)$; and $\mathrm{MC}$ were isolated by density centrifugation using Ficoll-Paque (Pharmacia Diagnostics AB, Uppsala, Sweden). Viability of the cells, checked by trypan blue exclusion, was always $>95 \%$. Subsequently, MC were cultured in $\mathrm{DMEM}^{+}$supplemented with $10 \%$ human male AB serum (Red Cross Blood Transfusion Centre, Utrecht, The Netherlands).

To assess proliferative activity, SFMC were cultured in 96-well plates for $4 \mathrm{~d}$ in the presence of different concentrations of Mycobacterium bovis hsp60 (which is $100 \%$ identical with M. tuberculosis hsp60; National Institute for Public Health and Environmental Protection, Bilthoven, The Netherlands), human hsp60 (Stressgen Biotechnologies Corp., Victoria, B.C., Canada), and/or different concentrations of IL-4 (Genzyme, Corp., Cambridge, MA). For both preparations, endotoxin concentration was $\leq 0.1 \mathrm{ng} / \mathrm{ml}$. During the last $18 \mathrm{~h}$ of culture, $1 \mu \mathrm{Ci}\left[{ }^{3} \mathrm{H}\right]$ thymidine was added to each well. Incorporated radioactivity was measured by liquid scintillation counting and expressed as counts per minute. The proliferative response is expressed as stimulation index $=$ mean counts per minute of cells cultured with antigen divided by mean counts per minute of cells cultured with medium alone.

For analysis of cytokine production (IFN- $\gamma$ and IL-4) by T cells activated with mycobacterial or human hsp60, SFMC were cultured in 24-well plates for $5 \mathrm{~d}$ in the presence of $3 \mu \mathrm{g} / \mathrm{ml}$ mycobacterial or

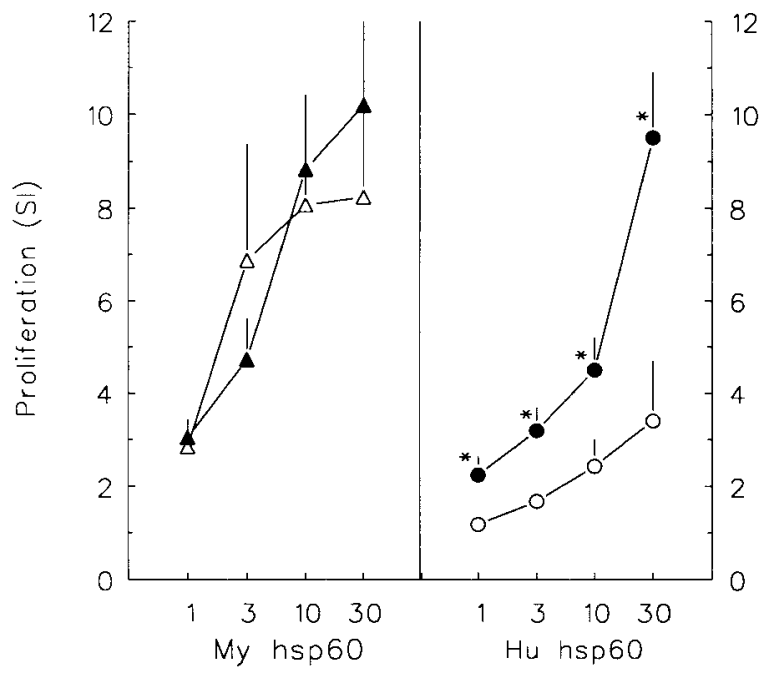

Figure 1. Proliferative responses (SI, stimulation index) of synovial fluid mononuclear cells from patients with RA $(n=5)$ in the presence of different concentrations of mycobacterial $(M y)$ or human $(\mathrm{Hu})$ 60-kD heat-shock protein in the absence (open symbols) or presence (closed symbols) of IL-4 $(200 \mathrm{U} / \mathrm{ml})$. Control proliferation of unstimulated cells induced by IL-4 $(200 \mathrm{U} / \mathrm{ml})$ was $1.72 \pm 0.2$. $* P \leq 0.05$ between proliferative responses in the absence and presence of IL-4. human hsp60. Spontaneous production of T cell cytokines by these $\mathrm{T}$ cells was found to be low or absent. Therefore, after antigen stimulation, T cell cytokine production was nonspecifically enhanced using mitogenic stimulation for an additional $2 \mathrm{~d}$ (anti-CD3/anti-CD28, dilution 1:1,000 vol/vol, CLB-T3/4.E, and CLB-CD28, respectively; CLB Reagentia, Amsterdam, The Netherlands; references 34, 35). This stimulus activates $\mathrm{T}$ cells through the $\mathrm{CD} 3$ complex together with the major costimulatory CD28-mediated signal. Both molecules are expressed on virtually all T cells in RA synovial fluid. After this culture period, conditioned media were harvested and freed of cellular material by centrifugation ( $5 \mathrm{~min}, 9,000 \mathrm{~g}$ ), frozen in liquid nitrogen, and stored at $-80^{\circ} \mathrm{C}$. IFN- $\gamma$ and IL- 4 were determined by ELISA according to the manufacturer's instructions (Medgenix, Flerus, Belgium). Detection limits were $50 \mathrm{pg} / \mathrm{ml}$ for IFN- $\gamma$ and $16 \mathrm{pg} / \mathrm{ml}$ for IL-4.

To test the inhibitory capacities of $\mathrm{T}$ cells generated in the presence of mycobacterial or human hsp60 $(10 \mu \mathrm{g} / \mathrm{ml})$, these activated $\mathrm{T}$ cells were amplified by an additional culture of $9 \mathrm{~d}$ in the presence of antigen and IL-2 $(10 \mathrm{U} / \mathrm{ml})$. Subsequently, these T cell lines (TCL) were harvested and their antigen specificity and suppressive activity were assessed. For this reason, the TCL $\left(2 \cdot 10^{5}\right)$ were cultured for $4 \mathrm{~d}$ in $96-$ well plates together with either irradiated $(4,000 \mathrm{rad})$ autologous PBMC as antigen-presenting cells $\left(4 \cdot 10^{5}\right)$ or freshly isolated nonirradiated autologous PBMC $\left(4 \cdot 10^{5}\right)$. To test antigen specificity, the TCL were pulsed during the last $18 \mathrm{~h}$ of culture with $1 \mu \mathrm{Ci}\left[{ }^{3} \mathrm{H}\right]$ thymidine/ well and assessed as described above. TNF- $\alpha$ production, measured by ELISA (detection limit $50 \mathrm{pg} / \mathrm{ml}$; Medgenix) was assessed to indicate inhibitory capacity of the TCL.

Statistical analysis. Statistical evaluation of differences in cytokine production and proliferation was performed by the Student's paired $t$ test. Data were judged statistically significant when $P \leq 0.05$.

\section{Results}

IL-4 stimulates MC proliferation induced by human but not bacterial hsp60. There was a significant correlation between stimulation indices obtained from proliferative responses of MC, induced by either human or mycobacterial hsp60 $(r=$ 0.893, $P \leq 0.001$, data not shown). The type of lymphocyte proliferation appeared to be different (Fig. 1). Lymphocyte proliferation in response was higher to mycobacterial than to human hsp60 (at $30 \mu \mathrm{g} / \mathrm{ml}, 8.28 \pm 3.26$ and $3.41 \pm 1.3$, respectively). The addition of IL-4 $(200 \mathrm{U} / \mathrm{ml})$ to mycobacterial hsp60-activated SFMC did not alter the level of proliferation, whereas IL-4 significantly enhanced human hsp60-induced proliferation at all concentrations (all $P \leq 0.05$; up to $278 \%$ at $30 \mu \mathrm{g} / \mathrm{ml}$ human hsp60). The proliferative response of SFMC treated with mycobacterial and human hsp60 $(3 \mu \mathrm{g} / \mathrm{ml})$ in the presence of varying concentrations of IL-4 is shown in Fig. 2. Lymphocyte proliferation of SFMC treated with mycobacterial hsp60 was significantly inhibited by adding $2 \mathrm{U} / \mathrm{ml}$ IL-4 $(P \leq 0.05)$, whereas it was not altered by 20 or $200 \mathrm{U} / \mathrm{ml} \mathrm{IL-4}$. In contrast, proliferation of SFMC treated with human hsp60 was stimulated significantly by 20 and $200 \mathrm{U} / \mathrm{ml}$ IL-4 (both $P \leq$ $0.05)$.

T cells stimulated with mycobacterial and human hsp60 differ in cytokine production. Fig. 3 shows the IFN- $\gamma$ and IL-4 production of mycobacterial and human hsp60-stimulated $\mathrm{T}$ cells (SFMC). IFN- $\gamma$ production of $\mathrm{T}$ cells stimulated with mycobacterial hsp60 was significantly higher than that of T cells stimulated with human hsp60 $(28 \%, P \leq 0.002)$. In contrast, IL-4 production of mycobacterial hsp60-stimulated T cells was significantly lower than that of $\mathrm{T}$ cells stimulated with human hsp60 $(29 \%, P \leq 0.05)$. This difference in T cell cytokine production was also observed when ratios of IFN- $\gamma$ and IL-4 for 


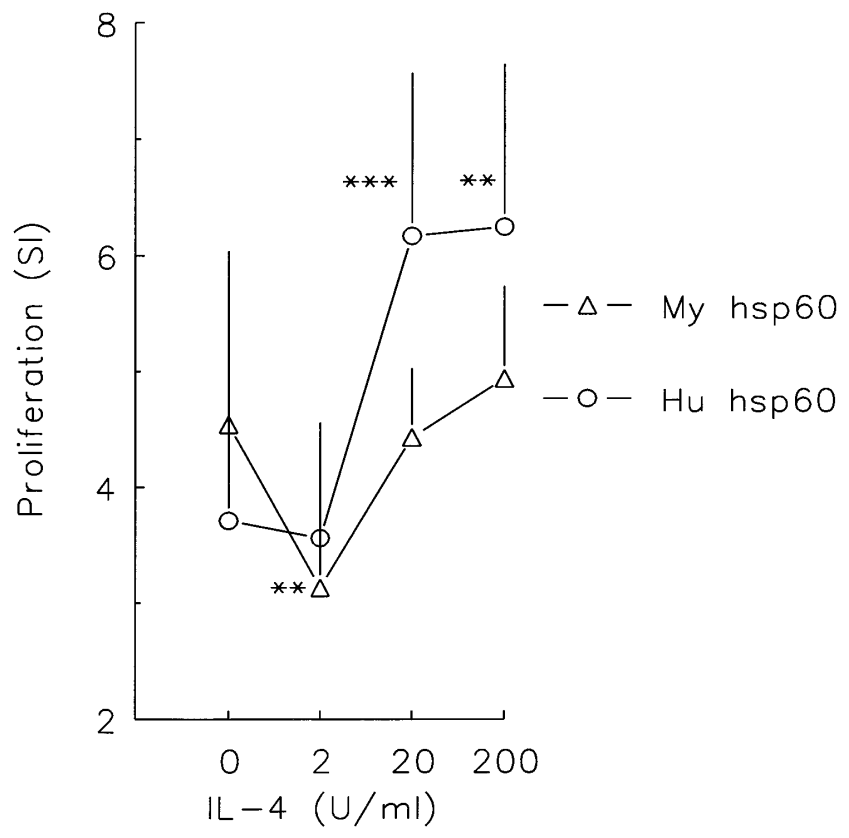

Figure 2. Effect of IL-4 on proliferative responses (SI, stimulation index) of synovial fluid mononuclear cells from patients with RA $(n=$ $11)$ induced by mycobacterial $(M y)$ or human $(H u)$ hsp60 $(3 \mu \mathrm{g} / \mathrm{ml})$. Control proliferation of unstimulated cells induced by IL-4 (200 $\mathrm{U} / \mathrm{ml}$ ) was $1.80 \pm 0.1 . * * P \leq 0.01$ and $* * * P \leq 0.001$ induced by IL-4.

mycobacterial and human hsp60-stimulated T cells of individual patients were compared (Fig. 3). The IFN- $\gamma /$ IL-4 ratio induced by mycobacterial hsp60 was $56 \%$ higher than the ratio induced by human hsp60 $(P \leq 0.004)$. In 18 of 20 patients, the IFN- $\gamma /$ IL-4 ratio after stimulation with human hsp60 was reduced (up to $78 \%$ ) compared with the IFN- $\gamma /$ IL-4 ratio of T cells stimulated with mycobacterial hsp60 (Fig. 4).

$T$ cell lines generated with human but not mycobacterial hsp60 suppress TNF- $\alpha$ production of PBMC. Fig. 5 shows that antigen-induced proliferation of the TCL generated in the presence of IL-2 after human or mycobacterial hsp60 stimulation. Proliferation of TCL specific for human hsp60 was $60 \%$ lower than that induced by mycobacterial hsp60. Human but not mycobacterial hsp60-specific TCL significantly $(P \leq 0.01)$ inhibited TNF- $\alpha$ production by PBMC. The increase in inhibition of TNF- $\alpha$ production correlated with a decrease in the proliferation of the TCL $(r=-0.71, P \leq 0.05)$.

\section{Discussion}

Despite their similarity with self antigens (36), bacterial hsps are exceptionally immunogenic antigens $(37,38)$. Experimental evidence has recently suggested that self hsp60-reactive $\mathrm{T}$ cells can exert antiinflammatory regulatory activities in human arthritides $(21,23,24,38)$. The strong reactivity towards self hsp60 of $\mathrm{T}$ cells obtained from children with remitting forms of juvenile chronic arthritis, which is most pronounced before phases of disease remission $(23,24)$, has further contributed to the understanding of the protective role of self hsp60.

The present data obtained with RA synovial fluid-derived mononuclear cells demonstrate that human hsp60-stimulated

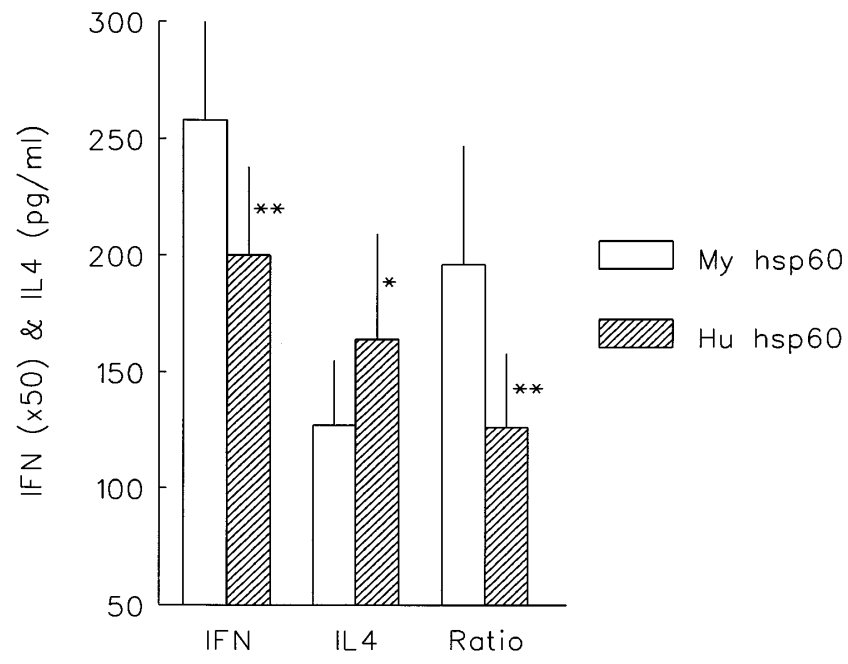

Figure 3. IFN- $\gamma$ and IL-4 production and the ratio of IFN- $\gamma /$ IL-4 of synovial fluid-obtained T cells from patients with RA $(n=20)$ cultured for $5 \mathrm{~d}$ in the presence of mycobacterial $(\mathrm{My})$ or human $(\mathrm{Hu})$ hsp60 $(3 \mu \mathrm{g} / \mathrm{ml})$ and an additional $2 \mathrm{~d}$ in the presence of anti-CD3/ anti-CD28 (days 5-7). $* P \leq 0.05$ and $* * P \leq 0.01$ between cells stimulated with My and Hu hsp60.

T cells are sensitive to IL-4, in contrast to mycobacterial hsp60stimulated T cells. The proliferative responses as observed can be interpreted in accordance with the notion that IL- 4 is a growth factor for $\mathrm{T}$ cells responding in a T2-like mode and that IL-4 is a factor that inhibits T1 cell activity (8). The persistence of proliferative responses towards mycobacterial hsp60 in the presence of higher concentrations of IL- 4 may be based on the induction of mycobacterial hsp60-dependent T2 or T0 cell activity. Since IL-4 in the absence of antigen does not induce significant proliferation, it could be that mycobacterial hsp60specific $\mathrm{T} 1$ cell activity is converted to $\mathrm{T} 2$ or $\mathrm{T} 0$ cell activity, a mechanism that has been demonstrated for other antigens (39).

Recently, we have shown that the production of IFN- $\gamma$ upon stimulation with mycobacterial hsp60 always exceeds that of IFN- $\gamma$ induced with human hsp60 $(1,393 \pm 359$ and $222 \pm 90$ $\mathrm{pg} / \mathrm{ml}$, respectively, $P<0.01)$. Restimulation of hsp60-stimu-

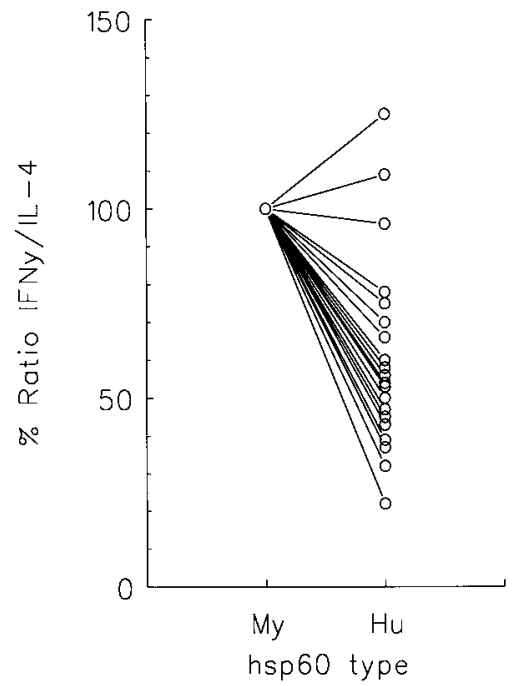

Figure 4. IFN- $\gamma / \mathrm{IL}-4$ ratios of synovial fluid $\mathrm{T}$ cells cultured for $5 \mathrm{~d}$ in the presence of mycobacterial $(M y)$ or human $(H u)$ hsp60 $(3 \mu \mathrm{g} /$ $\mathrm{ml})$ and an additional $2 \mathrm{~d}$ in the presence of anti-CD3/anti-CD28 (days 5-7). Lines indicate that for every patient the change in IFN- $\gamma /$ IL-4 ratio induced by Hu hsp60 compared with the ratio of IFN- $\gamma / \mathrm{IL}-4$ induced by My hsp60. The values for My hsp60 were put at $100 \%$. 

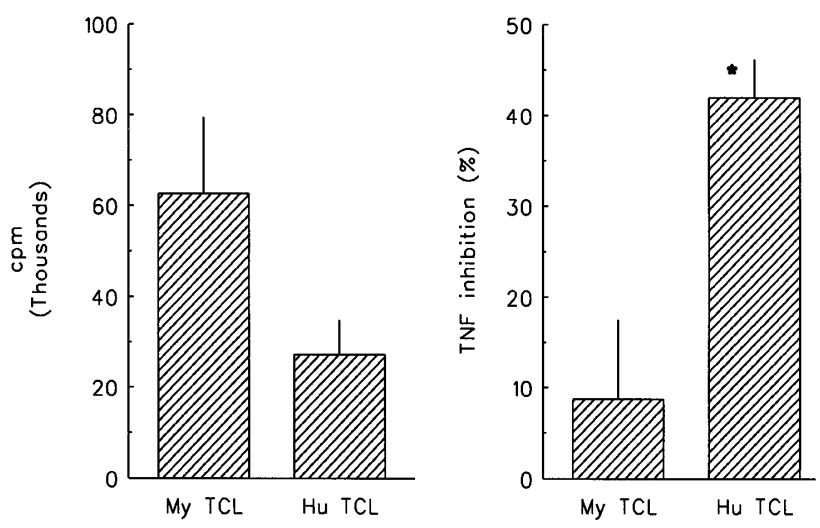

Figure 5. Antigen-induced proliferation (left) of T cell lines (TCL) specific for mycobacterial hsp60 (My TCL) and human hsp60 ( Hu $T C L$ ). Proliferation of My TCL and Hu TCL without antigen were 3,841 and 3,516 cpm, respectively. IFN- $\gamma / \mathrm{IL}-4$ ratios of $\mathrm{My}$ and $\mathrm{Hu}$ TCL were $620 \pm 180$ and $322 \pm 132$, respectively. Inhibition of TNF- $\alpha$ production by PBMC induced by addition of My TCL or Hu TCL is also shown (right axis). TNF- $\alpha$ production by PBMC without TCL $(516 \pm 277 \mathrm{pg} / \mathrm{ml})$ was put at $100 \%$. $* P \leq 0.01$.

lated T cells with anti-CD3/anti-CD28 resulted in a clear enhancement of IL-4 and IFN- $\gamma$ production. Mitogen-induced IFN- $\gamma$ significantly correlated with antigen-induced IFN- $\gamma$ production $(r=0.53, P<0.05, n=12)$. Similar analysis was not possible for IL-4, since hsp60-induced IL-4 production was below the detection limit. However, it has been shown that both IFN- $\gamma$ and IL-4 signals are efficiently enhanced by anti-CD3/ anti-CD28 $(34,35)$. Using the same restimulation, IFN- $\gamma$ production in mycobacterial hsp60-activated $\mathrm{T}$ cells was found to be higher than IFN- $\gamma$ production induced by human hsp60, whereas mycobacterial hsp60-induced IL-4 production was lower than IL-4 production by human hsp60. The more pronounced IFN- $\gamma$ over IL-4 production induced by mycobacterial hsp60 compared with human hsp60 is also indicative of stimulation of aggressive $\mathrm{T}$ cells by mycobacterial hsp60 and stimulation of regulatory T cell activity by human hsp60.

The present data are in line with previous observations that demonstrate that $\mathrm{T}$ cell reactivity towards hsp60 molecules can both suppress and induce arthritis. In several human arthritides, including RA, cellular and humoral responses towards mycobacterial hsp60 have been demonstrated and have been suggested to be involved in the induction of these arthritides $(31,32,40)$. The exact mechanisms by which bacterial hsp60specific $\mathrm{T}$ cells are activated in human but also experimental arthritis are unclear. However, these cells have been demonstrated to have an aggressive phenotype and to induce deleterious effects both in humans and animals $(9,36,41,42)$. By contrast, reactivity of $\mathrm{T}$ cells recognizing self hsp60 is accompanied by remission of experimental forms of arthritis and juvenile chronic arthritis (21-24). The present data show that such $\mathrm{T}$ cells, in contrast with mycobacterial hsp60-activated $\mathrm{T}$ cells, are able to suppress TNF- $\alpha$ production by PBMC.

Despite the difference in reactivity induced by the two types of hsp60, there is a strong correlation between mycobacterial and human hsp60-induced proliferation (this study, reference 23). Both of these proliferative responses were HLADR restricted (as measured in three RA patients, data not shown). These data, similar to experimental arthritis, suggest that in RA, hsp60-reactive T cells exist that recognize both mycobacterial and human hsp60. Examination of the epitopes from mycobacterial hsp60, which are recognized during induction and suppression of experimental arthritis, has provided a basis to explain both the inductive and suppressive modalities originating from mycobacterial and human hsp60 $(21,38)$. Based on these results and on the prominent correlation between mycobacterial and human hsp60-induced proliferation, it has been postulated that critical self epitopes form partial agonists of mycobacterial hsp60 epitopes. Reactive T cells may thereby be tuned to respond in a tolerizing or suppressive manner $(21,38)$. It has been shown that $\mathrm{T}$ cells that recognize partial agonists can lead to the production of suppressive cytokines (IL-4, TGF- $\beta$ ) with decreased levels of IL-2 and decreased proliferation $(43,44)$. This corroborates the present data showing lower $\mathrm{T}$ cell proliferation towards self hsp60 than to mycobacterial hsp60. Similarly, we show that human hsp60specific TCL proliferate less than mycobacterial-specific TCL and that increase in proliferation correlates with a decrease in the capacity to suppress proinflammatory cytokine production. With respect to this, T cell-stimulating cytokines such as IL-15 (45), which can be present in the RA joint, may contribute to the regulation of the activity of hsp60-reactive T cells.

On the basis of the present data, we postulate that human hsp60 and not mycobacterial hsp60 is an antigen that drives responding $T$ cells into a suppressive mode in patients with existing chronic RA. Thus, the human hsp60 molecule, as overexpressed in the arthritic synovium, can be a target of such cells, stimulating their disease-suppressive activity. It is possible that stimulation of suppressive $T$ cell activity by administration of human hsp60 molecules or cross-reactive conserved bacterial hsp60 epitopes is a promising way to mitigate RA, even in the case of established disease.

\section{Acknowledgments}

We thank Dr. R. van der Zee, Dr. J.D.A. van Embden, and the UNDP/World Bank/WHO Special Program for Research and Training in Tropical Diseases for providing the mycobacterial hsp60. Dr. A. Mulder is acknowledged for providing HLA antibodies.

This work was supported by the "Nationaal Reumafonds" (The Dutch League against Rheumatism).

\section{References}

1. Nouri, A.M.E., G.S. Panayi, and S.M. Goodman. 1984. Cytokines and chronic inflammation of rheumatic disease. I. The presence of IL-1 in synovial fluids. Clin. Exp. Immunol. 55:295-302.

2. Saxne, T., M.A. Palladino, D. Heinegard, N. Talal, and F.A. Wollheim. 1988. Detection of tumor necrosis factor $\alpha$ but not tumor necrosis $\beta$ in rheumatoid arthritis synovial fluid and serum. Arthritis Rheum. 31:1041-1046.

3. Westacott, C.I., J.T. Whicher, I.C. Barnes, D. Thompson, A.J. Swan, and P. Dieppe. 1990. Synovial fluid concentration of five different cytokines in rheumatic diseases. Ann. Rheum. Dis. 49:676-681.

4. Sipe, J.D., J. Martel-Pelletier, I.G. Otterness, and J.P. Pelletier. 1994. Cytokine reduction in the treatment of joint conditions. Mediat. Inflamm. 3:243-256.

5. Schulze-Koops, H., P.E. Lipsky, F. Kavanaugh, and L.S. Davies. 1995. Elevated TH1-like cytokine mRNA in the peripheral circulation of patients with rheumatoid arthritis: modulation by treatment with a monoclonal antibody to ICAM-1. J. Immunol. 155:5029-5037.

6. Dolhain, R.J.E.M., A.N. van der Heiden, N.T. ter Haar, F.C. Breedveld, and A.M.M. Miltenburg: 1996. Shift toward T lymphocytes with a T helper $1 \mathrm{cy-}$ tokine secretion profile in the joints of patients with rheumatoid arthritis. Arthritis Rheum. 39:1961-1969.

7. Simon, A.K., E. Seipelt, and J. Sieper. 1994. Divergent T-cell cytokine patterns in inflammatory arthritis. Proc. Natl. Acad. Sci. USA. 91:8562-8566.

8. Romagnani, S. 1994. Lymphokine production by human T-cells in disease 
states. Annu. Rev. Immunol. 12:227-257.

9. Van Roon, J.A.G., J.L.A.M. van Roy, A. Duits, F.P.J.G. Lafeber, and J.W.J. Bijlsma. 1995. Proinflammatory cytokine production and cartilage damage due to rheumatoid synovial T-helper-1 activation is inhibited by interleukin-4. Ann. Rheum. Dis. 54:836-840.

10. Miossec, P., J. Briolay, J. Dechanet, J. Wijdenes, H. Martinez-Valdez, and J. Banchereau. 1992. Inhibition of the production of proinflammatory cytokines and immunoglobulins by interleukin-4 in an ex vivo model of rheumatoid arthritis. Arthritis Rheum. 35:874-883.

11. Van Roon, J.A.G., J.L.A.M. van Roy, F.H.J. Gmelig-Meyling, F.P.J.G. Lafeber, and J.W.J. Bijlsma. 1996. Prevention and reversal of cartilage degradation by interleukin-10 and interleukin-4. Arthritis Rheum. 39:829-835.

12. Miossec, P., M. Naviliat, A. Dupuy D'Angeac, J. Sany, and J. Banchereau. 1990. Low levels of IL-4 and high levels of transforming growth factor $\beta$ in rheumatoid synovitis. Arthritis Rheum. 33:1180-1187.

13. Mauri, C., R.O. Williams, M. Walmsley, and M. Feldmann. 1996. Relationships between Th1/Th2 cytokine patterns and the arthritogenic response in collagen-induced arthritis. Eur. J. Immunol. 26:1511-1518.

14. Marceletti, J.F., J.I. Ohara, and D.H. Katz. 1991. Collagen-induced arthritis in mice. Relationship of collagen-specific and total IgE synthesis to disease. J. Immunol. 12:4185-4191.

15. Mutis, T., Y.E. Cornelisse, and T.H.M. Ottenhof. 1993. Mycobacteria induce CD4+ T cells that are cytotoxic and display Th1-like cytokine secretion profile: heterogeneity in cytotoxic activity and cytokine secretion. Eur. J. Immunol. 23:2189-2195.

16. Holoshitz, J., A. Matitiau, and I.R. Cohen. 1994. Arthritis induced in rats by cloned $\mathrm{T}$ lymphocytes responsive to mycobacterial hsp60 but not to collagen type II. J. Clin. Invest. 73:211-215.

17. Billingham, M.E.J., S. Carney, R. Butler, and M.J. Colston. 1990. A mycobacterial heat-shock protein induces antigen-specific suppression of adjuvant arthritis, but is not itself arthritogenic. J. Exp. Med. 171:339-344.

18. Ito, J., C.J. Krco, D. Yu, H.S. Luthra, and C.S. David. 1991. Preadministration of a $65 \mathrm{kDa}$ heat-shock protein, GroEL, inhibits collagen induced arthritis in mice. J. Cell Biochem. 15:284a. (Abstr.)

19. Van den Broek, M.F., E.J.M. Hogervorst, M.C.J. van Bruggen, W. van Eden, R. van der Zee, and W. van der Berg. 1989. Protection against streptococcal cell wall-induced arthritis by pretreatment with the $65-\mathrm{kD}$ mycobacterial heat-shock protein. J. Exp. Med. 170:449-466.

20. Thompson, S.J., G.A.W. Rook, R.J. Brealey, R. van der Zee, and C.J. Elson. 1990. Autoimmune reactions to heat-shock proteins in pristane-induced arthritis. Eur. J. Immunol. 20:2479-2484.

21. Anderton, S.M., R. van der Zee, B. Prakken, A. Noordzij, and W. van Eden. 1995. Activation of T cells recognizing self 60-kD heat-shock protein can protect against experimental arthritis. J. Exp. Med. 181:943-952.

22. Lopez-Guerrero, J.A., M.A. Ortiz, E. Paez, C. Bernabeu, and J.P. Lopez-bote. 1994. Therapeutic effect of recombinant vaccinia virus expressing the 60-kd heat-shock protein on adjuvant arthritis. Arthritis Rheum. 37:1462-1467.

23. De Graeff-Meeder, E.R., R. van der Zee, G.T. Rijkers, H.J. Schuurman, W. Kuis, J.W.J. Bijlsma, B.J.M. Zegers, and W. van Eden. 1991. Recognition of human heat-shock protein by mononuclear cells from patients with juvenile chronic arthritis. Lancet. 337:1368-1372.

24. De Graeff-Meeder, E.R., W. van Eden, G.T. Rijkers, B.J. Prakken, W. Kuis, M.M. Voorhorst-Ogink, R. van der Zee, H.J. Schuurman, P.J.M. Helders, and B.J.M. Zegers. 1995. Juvenile chronic arthritis: T cell reactivity to human HSP60 in patients with a favorable course of arthritis. J. Clin. Invest. 95:934-940.

25. Kleinau, S., K. Soderstrom, R. Kiessling, and L.A. Klareskog. 1991. A monoclonal antibody to the mycobacterial 65-kD heat-shock protein (ML 30) binds to cells in normal and arthritic joints of rats. Scand. J. Immunol. 33:195-202.

26. De Graeff-Meeder, E.R., M. Voorhorst, W. van Eden, H.J. Schuurman, J. Huber, D. Barkley, R.N. Maini, W. Kuis, G.T. Rijkers, and B.J.M. Zegers. 1990. Antibodies to the mycobacterial $65 \mathrm{kDa}$ heat-shock protein are reactive with synovial tissue of adjuvant arthritic rats and patients with rheumatoid arthritis and osteoarthritis. Am. J. Pathol. 137:1013-1017.
27. Karlsson-Parra, A., K. Soderstrom, M. Ferm, J. Ivanyi, R. Kiessling, and L. Klareskog. 1990. Presence of human heat-shock protein (hsp) in inflamed joints and subcutaneous nodules of RA patients. Scand. J. Immunol. 31:283-288.

28. Boog, C.J.P., E.R. de Graeff-Meeder, M.A. Lucassen, R. van der Zee, M.M. Voorhorst-Ogink, P.J.S. van Kooten, H.J. Geuze, and W. van Eden. 1992 Two monoclonal antibodies generated against human hsp60 show reactivity with synovial membranes of patients with juvenile chronic arthritis. J. Exp. Med. 175:1805-1810.

29. Sharif, M., J.G. Worrall, B. Singh, R.S. Gupta, P.M. Lydyard, C. Lambert, J. McCulloch, and G. Rook. 1992. The development of monoclonal antibodies to the human mitochondrial $60-\mathrm{kD}$ heat-shock protein, and their use in studying the expression of the protein in rheumatoid arthritis. Arthritis Rheum. 35:1427-1433.

30. Pope, R.M., R.M. Lovis, and R.S. Gupta. 1992. Activation of synovial fluid T lymphocytes by 60 -kd heat-shock proteins in patients with inflammatory arthritis. Arthritis Rheum. 35:43-48.

31. Res, P.C., F.C. Breedveld, J.D.A. van Embden, C.G. Schaar, W. van Eden, I.R. Cohen, and R.R.P. de Vries. 1988. Synovial fluid T cell reactivity against $65 \mathrm{kD}$ heat-shock protein of mycobacteria in early chronic arthritis. Lancet. ii:478-80.

32. Gaston, J.S.H., P.F. Life, L.C. Bailey, and P.A. Bacon. 1989. In vitro responses to a 65-kilodalton mycobacterial protein by synovial $\mathrm{T}$ cells from inflammatory arthritis patients. J. Immunol. 143:2494-2500.

33. Arnett, F.C., S.M. Edworthy, D.A. Bloch, D.J. McShane, J.F. Fries, N.S. Cooper, S.R. Healey, M.H. Liang, and H.S. Luthra. 1988. The American Rheumatism Association 1987 revised criteria for the classification of rheumatoid arthritis. Arthritis Rheum. 31:315-324.

34. Van der Pouw-Kraan, T., C. van Kooten, I. Rensink, and L. Aarden. 1992. Interleukin-4 production by human T cells. Differential regulation of IL-4 vs. IL-2 production. Eur. J. Immunol. 22:1237-1241.

35. June, C.H., J.A. Bluestone, L.M. Nadler, and C.B. Thompson. 1994. The B7 and CD28 receptor families. Immunol. Today. 15:321-331.

36. Welch, W.J. 1992. Mammalian stress response: cell physiology, structure/function of stress proteins, and implications for medicine and disease. Physiol. Rev. 72:1060-1079.

37. Albani, S., and D. Carson. 1996. A multistep molecular mimicry hypothesis for the pathogenesis of rheumatoid arthritis. Immunol. Today 10:466-470.

38. Van Eden, W., S.M. Anderton, R. van der Zee, B.J. Prakken, C.P.M. Broeren, and M.H.M. Wauben. 1996. (Altered) self peptides and the regulation of self reactivity in the peripheral T cell pool. Immunol. Rev. 149:55-73.

39. Mocci, S., and R.L. Coffman. 1996. Induction of a Th2 population from a polarized Leishmania-specific Th1 population by in vitro culture with IL-4. $J$. Immunol. 154:3779-3787.

40. Yssel, H., M.C. Shanafelt, C. Soderberg, P.V. Schneider, J. Anzola, and G. Peltz. 1991. Borrelia burgdorferi activates T-helper type 1-like T cell subset in Lyme arthritis. J. Exp. Med. 174:593-601.

41. Van Eden, W., J.R.E. Thole, R. van der Zee, A. Noordzij, J.D.A. van Embden, E.J. Hensen, and I.R. Cohen. 1988. Cloning of the mycobacterial epitope recognized by T lymphocytes in adjuvant arthritis. Nature (Lond.). 331: 171-173.

42. Wilbrink, B., M. Holewijn, J.W.J. Bijlsma, J.L.A.M. van Roy, W. den Otter, and W. van Eden. 1993. Suppression of human cartilage proteoglycan synthesis by rheumatoid synovial fluid mononuclear cells activated with mycobacterial $60 \mathrm{kD}$ heat-shock protein. Arthritis Rheum. 36:514-519.

43. Evavold, B.D., and P.M. Allen. 1991. Separation of IL-4 production from Th cell proliferation by an altered T cell receptor ligand. Science (Wash DC). 252:1308-1310.

44. Windhagen, A., C. Scholz, P. Hollsberg, H. Fukaura, A. Sette, and D.A Hafler. 1995. Modulation of cytokine patterns of human autoreactive $\mathrm{T}$ cell clones by a single amino acid substitution of their peptide ligand. Immunity. 2: 373-380.

45. Carson, D.A. 1997. Unconventional T cell activation by IL-15 in rheumatoid arthritis. Nat. Med. 3:148-149. 